\title{
HUBUNGAN ANTARA KARAKTERISTIK AGROEKOLOGI PERKEBUNAN KARET (Hevea brassiliansis L) DENGAN HASIL KARET DI LAMPUNG
}

\section{Correlation Between Characteristics of Rubber (Hevea Brassiliansis L) Agroecology with the Yield in Lampung}

\author{
Andarias Makka Murni* \\ Balai Pengkajian Teknologi Pertanian Lampung, Jl. Z.A. Pagar Alam No. 1a, Rajabasa Bandar Lampung, Indonesia
}

\begin{abstract}
Productivity of rubber (Hevea brassiliansis L) are determined by agro-ecological conditions in which the commodity is developed. Lampung province is one of the producers of the commodity. To determine the relationship between the characteristics of agroecology with rubber yield, the study of correlation of agroecological characteristics of the rubber yield was conducted in Lampung. The study was conducted at three locations, namely Tulang Bawang, Central Lampung and Way Kanan regency. The study used a survey method to collect rubber yield, as well as the character of agroecology including soil properties and climate data especially the rainfall based on the land evaluation guidelines for agricultural commodities. The results showed that the character of rubber plantations agroecology in Lampung belong to a class of suitable (S2). Soil fertility of rubber plantation in all locations generally at the level of low to moderate, except for potential K in Way Kanan and Tulang Bawang is high and available $P$ is high in all locations. Low soil pH and levels exchangeable Al at moderate to high level in the dept of 20-40 cm soil surface potentially to fix $P$ therefor making it unavailable to plants. There was a strong correlation between soil properties and yield of rubber in Tulang Bawang and Way Kanan, but in Central Lampung the relationship is very weak. Recommended land quality improvement technology in rubber plantations through liming and the use of organic materials to eliminate / prevent fixation of $P$ in the soil due to low soil pH and the levels of exchangeable Al at medium and high level in the layer 20-40 cm below the soil surface.
\end{abstract}

Keywords: Character agroecology, Hevea brassiliansis L, land suitability

\begin{abstract}
ABSTRAK
Produktivitas karet ditentukan oleh kondisi agroekologi dimana komoditas tersebut dikembangkan. Provinsi Lampung merupakan salah satu penghasil komoditi tersebut. Tujuan penelitian ini adalah untuk mengetahui hubungan antara karakteristik agroekologi dengan hasil karet di Provinsi Lampung. Kajian di tiga lokasi, yaitu Kabupaten Tulang Bawang, Lampung Tengah dan Way Kanan. Kajian menggunakan metode survey dengan cara mengumpulkan data produduksi karet, serta karakter agroekologi yang meliputi data sifat-sifat tanah dan iklim dengan berpedoman pada panduan evaluasi lahan untuk pewilayahan komoditas pertanian. Hasil kajian menunjukkan, bahwa karakter agroekologi perkebunan karet di Lampung termasuk ke dalam kelas sesuai (S2). Tingkat kesuburan tanah perkebunan karet di semua lokasi rata-rata rendah sampai sedang, kecuali kadar K potensial di Tulang Bawang dan Way Kanan tinggi dan $\mathrm{P}$ tersedia di semua lokasi tinggi. pH tanah yang rendah dan kadar Aldd pada taraf sedang sampai tinggi pada lapisan 20-40 cm di bawah permukaan tanah berpotensi untuk memfiksasi hara P sehingga tidak tersedia bagi tanaman. Terdapat hubungan yang sangat kuat antara faktor tanah dan hasil karet di Tulang Bawang dan Way Kanan, namun di Lampung Tengah hubungannya sangat lemah. Direkomendasikan teknologi perbaikan kualitas lahan di perkebunan karet melalui pengapuran dan penggunaan bahan organik untuk menghilangkan/mencegah terjadinya fiksasi $\mathrm{P}$ dalam tanah karena rendahnya $\mathrm{pH}$ tanah dan adanya kadar Aldd pada taraf sedang sampai tinggi pada lapisan $20-40 \mathrm{~cm}$ di bawah permukaan tanah.
\end{abstract}

Kata kunci: Karakter agroekologi, Hevea brassiliansis L, kesesuaian lahan

\section{PENDAHULUAN}

Karet (Hevea brassiliansis L) merupakan komoditas ekspor yang mampu memberikan kontribusi dalam upaya peningkatan devisa Indonesia. Sejumlah lokasi di Indonesia memiliki lahan yang cocok untuk pertanaman karet, sebagian besar berada di wilayah Sumatera dan Kalimantan.
Luas areal perkebunan karet di Lampung tahun 2011 adalah 97,598 ha, terdiri atas perkebunan rakyat seluas 69,662 ha, Perkebunan Swasta 10,303 ha dan Perkebunan Negara 17,633 ha (BPS Lampung, 2013). Produktivitas karet khusus untuk perkebunan rakyat di Lampung masih rendah, yaitu 0.9 ton $\mathrm{ha}^{-1}$, sementara produktivitas potensial yang bisa dicapai adalah 2 ton ha $^{-1}$ (Anwar, 2006; Dinas Perkebunan Provinsi Lampung, 2012; BPS Lampung, 2013). 
Produksi atau produktivitas karet ditentukan oleh kondisi agroekologi dimana komoditas tersebut dikembangkan. Berdasarkan klasifikasi kesesuaian zona agroekologi untuk tanaman karet pada lahan kering. Karakteristik agroekologi yang sesuai adalah curah hujan 2,000-4,000 mm, masa kering 1-2 bulan, drainase baik sedang, tekstur tanah halus-sedang, dengan $\mathrm{pH}$ 4.5-6.5 (Ritung et al., 2007; Anwar, 2006).

Perkembangan tanaman karet sangat cepat di Lampung, sedangkan lahan yang betul-betul memiliki agroekologi yang sesuai sudah terbatas. Akibatnya, petani maupun perkebunan swasta melakukan pengembangan ke lahan-lahan sub optimal yang tentunya karakter agroekologinya merupakan faktor pembatas pertumbuhan dan produksi tanaman.

Daerah yang cocok untuk tanaman karet (Hevea brassiliansis L) adalah pada zona antara $15^{\circ}$ LS dan $15^{\circ}$ LU. Diluar itu, pertumbuhan tanaman karet agak terhambat sehingga produksinya juga terlambat. Suhu udara yang baik bagi pertumbuhan tanaman antara 24-28 ${ }^{\mathrm{O}} \mathrm{C}$ (http://binaukm.com, 2010).

Hujan dapat mempengaruhi pertumbuhan dan perkembangan tanaman karet baik secara langsung dalam hal pemenuhan kebutuhan air bagi tanaman yang bervariasi menurut fase perkembangan tanaman, kondisi iklim dan tanah, maupun secara tidak langsung melalui pengaruh terhadap kelembaban udara dan tanah serta radiasi matahari. Ketiga faktor lingkungan fisik tersebut erat kaitannya dengan penyerapan air dan hara serta penyakit tanaman. Tanaman karet memerlukan curah hujan optimal antara 2,500 mm sampai 4,000 m tahun ${ }^{-1}$, dengan hari hujan (hh) berkisar antara $100 \mathrm{sd} .150 \mathrm{hh} \mathrm{tahun}^{-1}$. Namun demikian, jika sering hujan pada pagi hari, produksi akan berkurang (Anwar, 2006). Curah hujan yang berlebihan dapat menyebabkan gangguan pada penyadapan dan meningkatkan serangan penyakit. Serangan penyakit gugur daun Collectrichum yang berat terjadi pada wilayah dengan curah hujan diatas 3,000 mm tahun ${ }^{-1}$ (http://gtuneland.wordpress.com, 2011).

Kesesuaian lahan adalah kecocokan (adaptability) suatu lahan untuk tipe penggunaan lahan (jenis tanaman dan tingkat pengelolaan) tertentu (Djaenudin et al., 2000). Lahan kering (tanah) untuk pertumbuhan tanaman karet pada umumnya lebih mempersyaratkan sifat fisik tanah daripada sifat kimianya. Hal ini disebabkan karena perbaikan sifat kimia tanah lebih mudah dan murah dibanding dengan perbaikan sifat fisiknya. Berbagai jenis tanah dapat sesuai dengan syarat tumbuh tanaman karet baik tanah vulkanis muda dan tua, bahkan pada tanah gambut dengan ketebalan $<2 \mathrm{~m}$. Tanah vulkanis mempunyai sifat fisik yang cukup baik terutama struktur, tekstur, solum, kedalaman air tanah, aerasi dan drainasenya, tetapi sifat kimianya secara umum kurang baik karena kandungan haranya rendah. Tanah aluvial biasanya cukup subur, tetapi sifat fisiknya terutama drainase dan aerasinya kurang baik. Reaksi tanah yang diperlukan tanaman karet berkisar antara $\mathrm{pH} 3.0-\mathrm{pH} 8.0$ tetapi tidak sesuai pada $\mathrm{pH}<3.0$ dan $>\mathrm{pH}$ 8.0. Sifat-sifat tanah yang cocok untuk tanaman karet pada umumnya antara lain adalah solum tanah sampai $100 \mathrm{~cm}$, tidak terdapat batu-batuan dan lapisan cadas, aerasi dan drainase cukup baik, tekstur tanah remah, porous dan dapat menahan air, struktur terdiri atas $35 \%$ liat dan $30 \%$ pasir, dan $25 \%$ debu, tanah bergambut tidak lebih dari $20 \mathrm{~cm}$, kandungan hara $\mathrm{N}, \mathrm{P}$, dan $\mathrm{K}$ cukup dan tidak kekurangan unsur hara mikro, reaksi tanah dengan $\mathrm{pH} 4.5-\mathrm{pH} 6.5$, kemiringan tanah $<16 \%$ dan permukaan air tanah $<100$ cm (Anwar, 2006).

Kajian ini bertujuan untuk mengidentifikasi hubungan antara karakteristik agroekologi perkebunan tanaman karet dengan hasil karet di sentra tanaman karet di Lampung.

\section{BAHAN DAN METODE}

Pendekatan yang digunakan dalam kajian ini adalah pendekatan wilayah yang didasarkan atas karakteristik lokasi penyebaran tanaman karet. Karena produktivitas suatu tanaman ditentukan oleh kesesuaian agroekologinya dalam hal ini iklim dan tanah/lahan, maka perakitan teknologi dibuat melalui pendekatan karakteristik agroekologi yang meliputi sifat fisik dan kimia tanah, dan kondisi iklim terutama curah hujan. Masukan teknologi yang akan dibuat adalah upaya untuk mengatasi kendalakendala yang disebabkan faktor tanah, dan iklim mikro sampai pada batas-batas kesesuaian lahan dan iklim untuk tanaman karet, serta mempertimbangkan kemampuan adopsi petani.

Data sekunder berupa luas lahan dan produksi karet dikumpulkan dari kantor statistik baik Propinsi maupun Kabupaten di Lampung, Data yang dikumpulkan adalah data lima tahun terakhir. Data primer (produksi) diperoleh dari petani, perkebunan negara dan swasta. Pemilihan lokasi sebagai sumber data didasarkan kondisi zonasi agroekologi yang telah teridentifikasi. Data produksi diperoleh dari petani, perkebunanan negara dan perkebunan swasta. Untuk kepentingan analisis hubungan antara karakter agroekologi dan hasil tanaman, digunakan data hasil tanaman karet yang diperoleh dari petani di lokasi survey pengumpulan data agroekologi.

Karakterisasi agroekologi, dilakukan pada wilayah pengembangan karet yang telah dipilih sebagai lokasi sampel dan telah dikumpulkan data primer dan data sekundernya. Data karakter agroekologi yang dikumpulkan adalah data karakter/sifat-sifat lahan dan data iklim. Data karakter lahan diamati dengan berpedoman pada panduan evaluasi lahan untuk pewilayahan komoditas pertanian skala 1:50,000 melalui analisis terrain (Balittanah, 2003). Pada karakterisasi wilayah ini parameter yang dikumpulkan adalah kedalaman tanah, tekstur, drainase, reaksi tanah/pH, keadaan batuan dipermukaan dan di dalam penampang tanah, relief dan kemiringan lereng, gejala-gejala erosi, dan bahaya banjir. Analisis kimia contoh tanah terdiri atas penetapan $\mathrm{pH}$, kadar $\mathrm{C}$-organik (Walkley \& Black), N total, P dan $\mathrm{K}$ total ( $\mathrm{HCl} 25 \%), \mathrm{P}$ tersedia (Bray1), basa-basa dapat ditukar, KTK, kejenuhan basa, dan kadar Al (metode titrasi (larutan baku $\mathrm{HCl} 0.020$ N) dilakukan di laboratorium tanah BPTP Lampung. Data penunjang lainnya yang perlu dikumpulkan adalah data iklim, yaitu curah hujan untuk jangka waktu 5-10 tahun terakhir. Data tersebut dikumpulkan dari stasiun iklim terdekat dengan lokasi pengkajian.

Data hasil pengkajian dianalisis statistik dengan metode analisis regresi atau korelasi digunakan untuk mengetahui hubungan antara karakter agroekologi dengan produksi karet. 


\section{HASIL DAN PEMBAHASAN}

\section{Luas dan Produksi Karet di Lampung}

Perkebunan karet rakyat terluas terdapat di Kabupaten Tulang Bawang, Way Kanan dan Lampung Utara, sedangkan perkebunan besar swasta (PBS) terluas di Way Kanan, Tulang Bawang, dan Lampung Barat, dan perkebunan besar negara (PBN) hanya terdapat di Lampung Selatan dan Lampung Utara. Produktivitas karet rakyat masih sangat rendah, yaitu rata-rata 0.5 ton $\mathrm{ha}^{-1}$, sedangkan PBS dan PBN masing-masing sudah mencapai 1.8 dan 1.0 ton ha ${ }^{-1}$. Hal ini menunjukkan bahwa masih terdapat senjang hasil yang tinggi antara perkebunan rakyat dan PBS dan PBN. Senjang hasil ini mungkin disebabkan oleh penerapan teknologi di tingkat petani masih rendah atau kelas kesesuaian lahan yang kurang sesuai. Data luas areal dan produksi perkebunan karet di Lampung disajikan pada Tabel 1.

Tabel 1. Luas areal dan produksi karet di Lampung

\begin{tabular}{|c|c|c|c|c|c|c|c|}
\hline \multirow{2}{*}{ No } & \multicolumn{3}{|c|}{ Perkebunan Rakyat } & \multicolumn{2}{|c|}{ PBS } & \multicolumn{2}{|c|}{ PBN } \\
\hline & Kabupaten & Luas (ha) & Produksi (ton) & Luas (ha) & Produksi (ton) & Luas (ha) & Produksi (ton) \\
\hline 1 & Lampung Selatan & 844 & 415 & & & 12,122 & 10,779 \\
\hline 2 & Pesawaran & 511 & 322 & & & & \\
\hline 3 & Lampung Tengah & 963 & 427 & & & & \\
\hline 4 & Lampung Timur & 777 & 246 & & & & \\
\hline 5 & Lampung Utara & 11,807 & 7,652 & 969 & 833 & 5,511 & 7,712 \\
\hline 6 & Way Kanan & 23,827 & 10,833 & 5,000 & - & & \\
\hline 7 & Lampung Barat & 227 & & 1,799 & 6,797 & & \\
\hline 8 & Tulang Bawang & 30,422 & 13,201 & 3,695 & 5,204 & & \\
\hline 9 & Tanggamus & 214 & 45 & 639 & 266 & & \\
\hline 10 & B. Lampung & 70 & 3 & & & & \\
\hline 11 & Total & 69,662 & 33,144 & 12,102 & 13,100 & 17,633 & 18,491 \\
\hline
\end{tabular}

Sumber: Dinas Perkebunan Provinsi Lampung Tahun 2012

\section{Kondisi Iklim Lokasi Kajian}

Berdasarkan jumlah curah hujan bulanan, Smith dan Ferguson (1951) membagi curah hujan bulanan ke dalam 3 kelas, yaitu:

a. Bulan Kering (BK), bila curah hujan bulanan $<60 \mathrm{~mm}$,

b. Bulan Lembab (BL), bila curah hujan bulanan $60-100$ $\mathrm{mm}$,

c. Bulan Basah (BB) bila curah hujan bulanan $>100 \mathrm{~mm}$

Dari kriteria tersebut ditentukan tipe iklim, menggunakan nilai $\mathrm{Q}$ dengan rumus sebagai berikut:

Rata-rata Bulan Kering (KK)

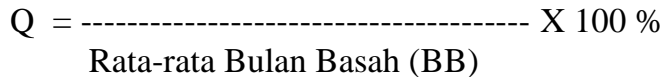

Berdasarkan formula tersebut ditentukan tipe iklim dengan ketentuan:

a. Tipe A : apabila nilai $\mathrm{Q}<14.3 \%$; daerah sangat basah

b. Tipe B : apabila nilai $\mathrm{Q}=14.3-33.3 \%$; daerah basah

c. Tipe $\mathrm{C}$ : apabila nilai $\mathrm{Q}=33.3-60 \%$; daerah agak basah

d. Tipe D : apabila nilai $\mathrm{Q}=60-100 \%$; daerah sedang

e. Tipe E : apabila nilai $\mathrm{Q}=100-167 \%$; daerah agak kering

f. Tipe $\mathrm{F}$ : apabila nilai $\mathrm{Q}=167-300 \%$; daerah kering

g. Tipe $\mathrm{G}$ : apabila nilai $\mathrm{Q}=300-700 \%$

h. Tipe $\mathrm{H}$ : apabila nilai Q > 700\%; daerah ekstrim kering.

Penggolongan tipe iklim menurut Smith dan Ferguson tersebut dijadikan rujukan untuk menentukan tipe iklim di lokasi kajian.

\section{Kondisi Iklim Kabupaten Tulang Bawang}

Distribusi rata-rata curah hujan di Tulang Bawang secara umum menunjukkan bahwa puncak hujan (curah hujan tertinggi) terjadi pada bulan Desember - Maret, sedangkan lembah hujan (curah hujan terendah) terjadi pada bulan Agustus dan September (Gambar 1). Rata-rata curah hujan tahunan adalah 2,223 mm dengan bulan kering 3 bulan dan bulan basah 8 bulan. Distribusi curah hujan setiap tahunnya, menunjukkan adanya tahun dengan bulan kering sampai 6 bulan, bahkan selama 10 tahun ada tiga tahun terjadi lebih dari 3 bulan kering yaitu pada tahun 2003; 2006 dan 2008. Nilai Q berdasarkan data curah hujan di Tulang Bawang adalah 37.5\%.

Berdasarkan nilai Q di atas, maka klasifikasi iklim di Tulang Bawang menurut Schmidt dan Ferguzon (1951) tergolong iklim tipe C. Berdasarkan kesesuaian lahan dan iklim tanaman karet (Tabel 2), maka ilkim Tulang Bawang tergolong ke dalam kelas kesesuaian S2. Kejadian bulan kering yang ekstrim ( 3 tahun dalam kurun waktu 10 tahun) akan menghambat produksi karet (Anwar, 2006; Sasongko, 2010). Kejadian bulan kering penting unuk dijadikan acuan dalam menentukan kelas kesesuaian iklim, karena bila sering terjadi bulan kering, penurunan produksi juga akan sering terjadi dan proses pemulihan pertumbuhan tanaman akibat pengaruh kemarau panjang tersebut akan membutuhkan waktu yang cukup lama dan membutuhkan tambahan biaya usahatani yang tinggi.

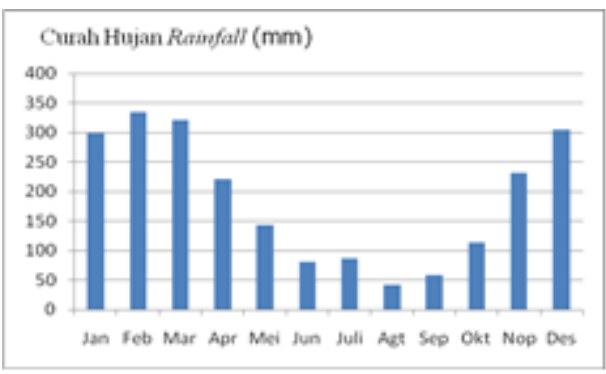

Gambar 1. Pola curah hujan rata-rata (10 tahun) Kabupaten Tulang Bawang 
Tabel 2. Kelas kesesuaian lahan dan iklim untuk tanaman karet

\begin{tabular}{|c|c|c|c|c|}
\hline \multirow{2}{*}{ Persyaratan Penggunaan/ Karakteristik Lahan } & \multicolumn{4}{|c|}{ Kelas Kesesuaian Lahan } \\
\hline & S1 & $\mathrm{S} 2$ & S3 & $\mathrm{N}$ \\
\hline \multicolumn{5}{|l|}{ Temperatur (tc) } \\
\hline Temperatur rata-rata $\left({ }^{\circ} \mathrm{C}\right)$ & $26-30$ & $30-34$ & $22-24$ & $>34 ;<22$ \\
\hline Curah Hujan (mm) & $2500-3000$ & $\begin{array}{l}2000-2500 \\
3000-3500\end{array}$ & $1500-2000 ; 3500-4000$ & $<1500 ;>4000$ \\
\hline Lama Bulan Kering (bulan) & $1-2$ & $2-3$ & $3-4$ & $>4$ \\
\hline Drainase & Baik & Sedang & $\begin{array}{l}\text { agak terhambat, } \\
\text { terhambat }\end{array}$ & $\begin{array}{c}\text { sangat terhambat, } \\
\text { cepat }\end{array}$ \\
\hline Tekstur & $\begin{array}{l}\text { halus, agak halus, } \\
\text { sedang }\end{array}$ & - & agak kasar & Kasar \\
\hline Bahan Kasar (\%) & $<15$ & $15-35$ & $36-60$ & $>60$ \\
\hline Kedalaman Tanah $(\mathrm{cm})$ & $>100$ & $75-100$ & $50-75$ & $<50$ \\
\hline Kejenuhan Basa (\%) & $<35$ & $35-50$ & $>50$ & - \\
\hline $\mathrm{pH}\left(\mathrm{H}_{2} \mathrm{O}\right)$ & $5.0-6.0$ & $6.0-6.5 ; 4.5-5.0$ & $>6.5 ;<4.5$ & - \\
\hline C-organik (\%) & $>0.8$ & $\leq 0.8$ & & \\
\hline Salinitas $\left(\mathrm{dS} \mathrm{m}{ }^{-1}\right)$ & $<0.5$ & $0.5-1$ & $1-2$ & $>2$ \\
\hline Kedalaman Sulfidik (cm) & $>175$ & $125-175$ & $75-125$ & $<75$ \\
\hline \multicolumn{5}{|l|}{ Bahaya Erosi (eh) } \\
\hline Lereng $(\%)$ & $<8$ & $8-16$ & $\begin{array}{l}16-30 \\
16-45\end{array}$ & $>30 ;>45$ \\
\hline Bahaya Erosi & sangat rendah & rendah-sedang & berat & sangat berat \\
\hline \multicolumn{5}{|l|}{ Bahaya Banjir (fh) } \\
\hline Genangan & F0 & - & $\mathrm{F} 1$ & $>\mathrm{F} 1$ \\
\hline \multicolumn{5}{|l|}{ Penyiapan Lahan (lp) } \\
\hline Batuan di permukaan (\%) & $<5$ & $5-15$ & $15-40$ & $>40$ \\
\hline Singkapan Batuan & $<5$ & $5-15$ & $15-25$ & $>25$ \\
\hline
\end{tabular}

Sumber: Djaenudin et al., (2000)

\section{Kondisi Iklim Kabupaten Lampung Tengah}

Distribusi rata-rata curah hujan di Lampung Tengah secara umum menunjukkan bahwa puncak hujan (curah hujan tertinggi) terjadi pada bulan Januari, sedangkan lembah hujan (curah hujan terendah) terjadi pada bulan Agustus (Gambar 2). Rata-rata curah hujan tahunan adalah 1,486 $\mathrm{mm}$ dengan bulan kering 3 bulan dan bulan basah 7 bulan. Distribusi curah hujan tahunan menunjukkan, terdapat tahun dengan bulan kering sampai 6 bulan, bahkan selama 7 tahun ada tiga tahun terjadi lebih dari 3 bulan kering yaitu pada tahun 2001; 2002 dan 2004. Berdasarkan klasifikasi iklim menurut Smith dan Ferguzon Lampung Tengah memiliki nilai $\mathrm{Q}=42.8 \%$ yang berarti tergolong tipe iklim C. Dengan merujuk kepada kesesuaian iklim dan lahan untuk tanaman karet (Tabel 2), rata-rata curah hujan tahunan maupun kejadian bulan kering, maka dapat dikatakan bahwa iklim Lampung Tengah tergolong kedalam kelas S2 untuk tanaman karet. Kejadian bulan kering yang ekstrim (3 tahun dalam kurun waktu 7 tahun) akan menghambat produksi karet (Anwar, 2006; Sasongko, 2010). Rata-rata curah hujan dan distribusinya, serta kejadian bulan kering penting unuk dijadikan acuan dalam menentukan kelas kesesuaian iklim untuk tanaman karet, karena bila curah hujan rendah dan sering terjadi bulan kering, maka suplai air untuk pertumbuhan akan terhambat sehingga produksi juga akan menurun. Tanaman karet akan lebih sering mengalami pengaruh kekurangan air di Lampung Tengah, karena tanaman karet membutuhkan air yang cukup banyak.

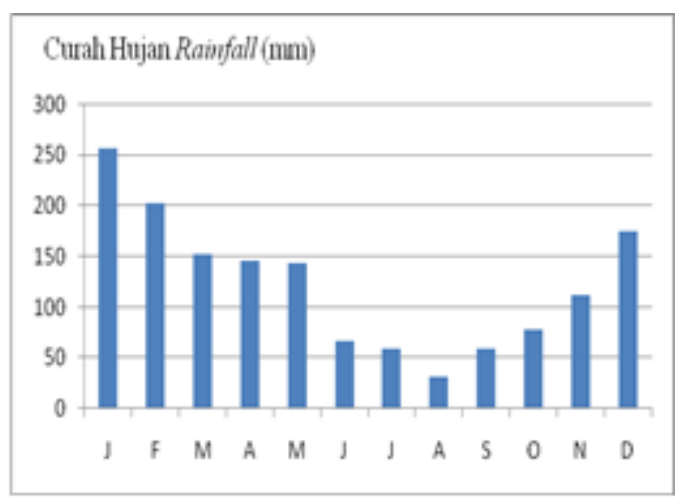

Gambar 2. Pola curah hujan rata-rata 7 tahun di Lampung Tengah 


\section{Kondisi Iklim Kabupaten Way Kanan}

Distribusi rata-rata curah hujan di Way Kanan secara umum menunjukkan bahwa puncak hujan (curah hujan tertinggi) terjadi pada bulan Desember - April, sedangkan lembah hujan (curah hujan terendah) terjadi pada bulan Juli dan Agustus (Gambar 3). Rata-rata curah hujan tahunan adalah 2,444 $\mathrm{mm}$ dengan bulan kering $<2$ bulan dan bulan basah 9 bulan. Bila diperhatikan distribusi setiap tahunnya, bulan kering paling tinggi 3 bulan, bahkan ada bulan tanpa bulan kering. Nilai Q berdasarkan data curah hujan di Way Kanan tersebut adalah $17.8 \%$.

Berdasarkan nilai Q di atas, maka klasifikasi iklim di Way Kanan menurut Smith dan Ferguzon tergolong iklim tipe B. Dengan merujuk kepada kesesuaian iklim dan lahan untuk tanaman karet (Tabel 2), rata-rata curah hujan tahunan maupun bulan kering, maka iklim di Way Kanan memenuhi persyaratan tumbuh tanaman karet dan tergolong kelas S1. Pola curah hujan seperti pada Gambar 3, sangat mendukung untuk menyuplai kebutuhan air untuk pertumbuhan dan produksi karet di Way Kanan.

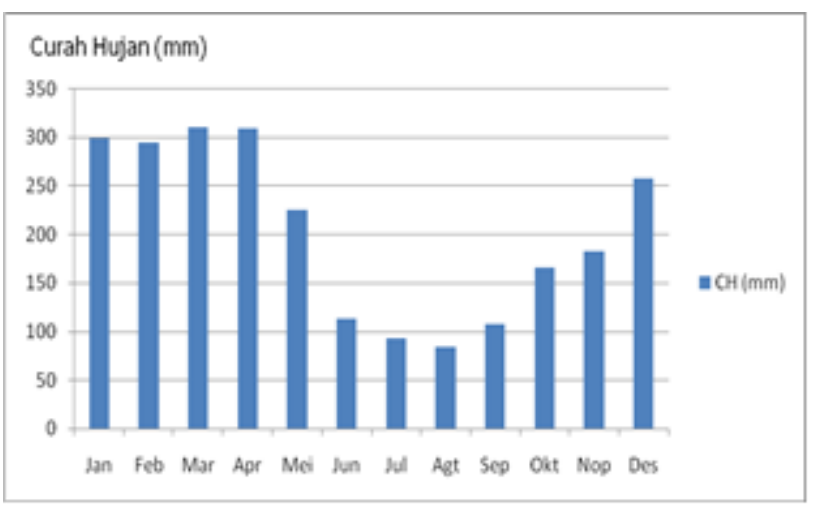

Gambar 3. Pola curah hujan Kabupaten Way Kanan

\section{Kesesuaian Lahan.}

Untuk mengetahui apakah lahan tersebut sesuai atau tidak untuk tanaman, FAO (1983) membagi kelas kesesuaian lahan untuk tanaman sebagai berikut:

Kelas S1 : Lahan tidak mempunyai faktor (Sangat pembatas yang berarti atau nyata sesuai) terhadap penggunaan secara berkelanjutan, atau faktor pembatas bersifat minor dan tidak akan berpengaruh terhadap produktivitas lahan secara nyata.
Kelas S2

(Sesuai)

Kelas S3

(Sesuai

Marginal)

Kelas N

(Tidak

Sesuai)
: Lahan mempunyai faktor pembatas, dan faktor pembatas ini akan berpengaruh terhadap produktivitasnya, memerlukan tambahan masukan (input). Pembatas tersebut biasanya dapat diatasi oleh petani sendiri.

: Lahan mempunyai faktor pembatas yang berat, dan faktor pembatas ini akan sangat berpengaruh terhadap produktivitasnya, memerlukan tambahan masukan yang lebih banyak daripada lahan yang tergolong S2. Untuk mengatasi faktor pembatas pada S3 memerlukan modal tinggi, sehingga perlu adanya bantuan atau campur tangan (intervensi) pemerintah atau pihak swasta.

: Lahan yang karena mempunyai faktor pembatas yang sangat berat dan/atau sulit diatasi.

\section{Kesesuaian Lahan Tanaman Karet}

Berdasarkan kesesuaian iklim untuk tanaman karet, Tulang Bawang dan Lampung Tengah termasuk kedalam kelas kesesuaian S2, sedangkan Way Kanan termasuk kelas S1 (Tabel 2). Menurut Anwar (2006), tanaman karet memerlukan curah hujan optimal antara 2,500 mm sampai 4,000 mm tahun ${ }^{-1}$, dengan hari hujan berkisar antara 100 sd. 150 hh tahun ${ }^{-1}$. Namun demikian, jika sering hujan pada pagi hari, produksi akan berkurang. Menurut Djaenudin et al. (2000), kondisi iklim dengan bulan kering kurang dari 2 bulan berturut-turut sesuai untuk tanaman karet, sedangkan di Tulang Bawang dan Lampung Tengah rata-rata bulan kering 3 bulan.

Berdasarkan kriteria kesesuaian lahan yang dikemukakan oleh Ritung et al. (2007) di atas, maka lahan perkebunan karet di Tulang Bawang, Lampung Tengah dan Way Kanan termasuk kelas S2 karena sebagian karakteristik tanahnya masuk ke dalam S2 (kedalaman tanah, pH dan KTK) seperti yang ditunjukkan pada Tabel 3. Sekalipun karakteristik lahannya termasuk kelas S2, namun faktor penghambatnya masih dapat diatasi sendiri oleh petani, karena faktor pembatasnya tergolong ringan. Faktor pH tanah dan KTK yang rendah dapat diatasi melalui pengapuran dan penambahan bahan organik. 
Tabel 3. Kelas kesesuaian lahan tanaman karet berdasarkan hasil pengamatan karakteristik agroekologi perkebunan karet di Lampung

\begin{tabular}{|c|c|c|c|c|c|c|}
\hline \multirow{2}{*}{$\begin{array}{l}\text { Persyaratan Penggunaan/ Karakteristik } \\
\text { Lahan }\end{array}$} & \multicolumn{2}{|c|}{ Tulang Bawang } & \multicolumn{2}{|c|}{ Lampung Tengah } & \multicolumn{2}{|c|}{ Way Kanan } \\
\hline & Nilai & Kelas & Nilai & Kelas & Nilai & Kelas \\
\hline Temperatur rata-rata $\left({ }^{\circ} \mathrm{C}\right)$ & 27.9 & S1 & - & - & 27.3 & S1 \\
\hline Curah Hujan (mm) & 2,222 & S2 & 1,486 & S2 & 2,444 & S1 \\
\hline Lama Bulan Kering (bulan) & 3 & S2 & 3 & $\mathrm{~S} 2$ & $<2$ & S1 \\
\hline Drainase & $\begin{array}{c}\text { agak } \\
\text { terhambat }\end{array}$ & S2 & agak baik & S1 & $\begin{array}{l}\text { baik, } \\
\text { sedang }\end{array}$ & S1 \\
\hline Tekstur & agak halus & S1 & agak halus & S1 & agk halus & S1 \\
\hline Bahan Kasar (\%) & $<15 \%$ & S1 & $<15 \%$ & S1 & $<15 \%$ & S1 \\
\hline Kedalaman Tanah $(\mathrm{cm})$ & $<100$ & S2 & $<100$ & S2 & 75 & $\mathrm{~S} 2$ \\
\hline KTK liat (cmol) & 15.8 & S2 & 15.9 & $\mathrm{~S} 2$ & 16.8 & S1 \\
\hline Kejenuhan Basa (\%) & - & - & - & - & - & - \\
\hline $\mathrm{pH}\left(\mathrm{H}_{2} \mathrm{O}\right)$ & 4.5 & S2 & 4.36 & S2 & 4.59 & S2 \\
\hline C-organik & 2.38 & S1 & 1.99 & S1 & 2.9 & S1 \\
\hline Lereng $(\%)$ & $0-8 \%$ & S1 & $0-8 \%$ & S1 & $<8 \%$ & S1 \\
\hline Bahaya Erosi & $\begin{array}{l}\text { Sangat } \\
\text { Rendah }\end{array}$ & S1 & Rendah & S1 & $\begin{array}{l}\text { Rendah, } \\
\text { sedang }\end{array}$ & S2 \\
\hline \multicolumn{7}{|l|}{ Bahaya Banjir (fh) } \\
\hline Bahaya Banjir (fh) : Genangan & F0 & S1 & $\mathrm{F} 1$ & S3 & F0 & S1 \\
\hline Batuan di permukaan (\%) & $0-5 \%$ & S1 & $0-5 \%$ & S1 & $0-5 \%$ & S1 \\
\hline Singkapan Batuan & $0-5 \%$ & S1 & $0-5 \%$ & S1 & $0-5 \%$ & S1 \\
\hline Kelas Kesesuaian Lahan & & $\mathrm{S} 2$ & & $\mathrm{~S} 2$ & & S2 \\
\hline
\end{tabular}

\section{Tingkat Kesuburan Tanah Perkebunan Karet}

Hasil analisis tanah perkebunan karet lokasi kajian (Tabel 4) menunjukkan, bahwa $\mathrm{pH}$ tanah pada umumnya rendah, yaitu $<5.0$. Kadar $\mathrm{C}$ organik tergolong sedang di Tulang Bawang dan Way Kanan, tetapi rendah di Lampung Tengah. Kandungan $\mathrm{N}$ rendah di Tulang Bawang dan Lampung Tengah dan sedang di Way Kanan. $P$ potensial rendah di Tulang Bawang, sedangkan di Way Kanan dan Lampung Tengah statusnya sedang, sementara itu status $\mathrm{P}$ tersedia (Bray-1) tinggi di semua lokasi. K potensial tinggi di Tulang Bawang dan Way Kanan, namun rendah di Lampung Tengah. Kation dapat ditukar umumnya statusnya sedang, kecuali $\mathrm{Ca}$ tergolong rendah di semua lokasi, bahkan di Lampung Tengah sangat rendah. Walaupun $\mathrm{pH}$ tanah tergolong rendah, namun kejenuhan Al tanah tidak tinggi, kecuali pada lapisan 20$40 \mathrm{~cm}$ di bawah permukaan tanah yang berstatus sedang. Kondisi ini potensial untuk mempengaruhi kejenuhan $\mathrm{Al}$ pada lapisan perakaran tanaman karet.

Tabel 4. Kesuburan tanah perkebunan karet di Kabupaten Tulang Bawang, Way Kanan dan Lampung Tengah.

\begin{tabular}{|c|c|c|c|c|c|c|}
\hline \multirow{2}{*}{ Komponen Analisis } & \multicolumn{2}{|c|}{ Tulang Bawang } & \multicolumn{2}{|c|}{ Way Kanan } & \multicolumn{2}{|c|}{ Lampung Tengah } \\
\hline & $0-20$ & $20-40$ & $0-20$ & $20-40$ & $0-20$ & $20-40$ \\
\hline \multirow[t]{2}{*}{$\mathrm{pH}$} & 4.52 & 4.47 & 4.58 & 4.39 & 4.36 & 4.21 \\
\hline & 3.97 & 3.90 & 4.03 & 3.90 & 3.79 & 3.70 \\
\hline \multirow{3}{*}{$\begin{array}{l}\% \text { C-organik } \\
\% \mathrm{~N} \\
\text { P-Bray (ppm) }\end{array}$} & 2.38 & 1.98 & 3.12 & 1.98 & 1.99 & 1.50 \\
\hline & 0.20 & 0.13 & 0.24 & 0.18 & 0.20 & 0.15 \\
\hline & 23.01 & 12.21 & 20.69 & 14.15 & 34.15 & 25.82 \\
\hline \multirow{3}{*}{$\begin{array}{l}\mathrm{P} \mathrm{HCl} 25 \%\left(\mathrm{mg} \mathrm{P}_{2} \mathrm{O}_{5} 100 \mathrm{~g}^{-1}\right) \\
\mathrm{K} \mathrm{HCl} 25 \%\left(\mathrm{mg} \mathrm{K}_{2} \mathrm{O} 100 \mathrm{~g}^{-1}\right) \\
\mathrm{KTK}\left(\mathrm{cmol} \mathrm{kg}^{-1}\right)\end{array}$} & 15.85 & 11.40 & 22.20 & 17.60 & 23.04 & 17.06 \\
\hline & 47.02 & 37.85 & 52.11 & 33.67 & 14.23 & 11.17 \\
\hline & 15.85 & 14.64 & 16.82 & 16.98 & 15.90 & 13.54 \\
\hline \multicolumn{7}{|l|}{ Kation dapat ditukar $\left(\mathrm{cmol} \mathrm{kg}^{-1}\right)$} \\
\hline K-dd & 0.54 & 0.30 & 0.56 & 0.47 & 0.73 & 0.63 \\
\hline $\mathrm{Na}-\mathrm{dd}$ & 0.46 & 0.42 & 0.49 & 0.44 & 0.58 & 0.50 \\
\hline Ca-dd & 2.25 & 1.61 & 3.86 & 2.84 & 1.49 & 1.30 \\
\hline Mgdd & 0.39 & 0.43 & 1.21 & 19.52 & 0.51 & 0.58 \\
\hline Al-dd & 1.49 & 1.67 & 1.74 & 3.07 & 1.14 & 1.71 \\
\hline Kejenuhan $\mathrm{Al}(\%)$ & 9.51 & 11.47 & 10.00 & 17.89 & 7.23 & 12.77 \\
\hline H-dd & 0.16 & 0.19 & 0.28 & 1.03 & 0.18 & 0.24 \\
\hline
\end{tabular}


Berdasarkan tingkat kesuburan tanahnya, maka diperlukan perbaikan kesuburan tanah melalui pemberian kapur dan bahan organik untuk meningkatkan $\mathrm{pH}$ tanah menjadi $\geq 5$ agar optimal untuk pertumbuhan tanaman karet. Penambahan bahan organik diperlukan untuk meningkatkan daya sanggah tanah terhadap air dan hara, terutama di Lampung Tengah, mengingat di lokasi tersebut pola curah hujan agak rendah dan bulan kering lebih dari 3 bulan.

\section{Pengaruh Karakter Agroekologi terhadap Produktivitas Karet}

Untuk mengetahui ada tidaknya hubungan atau pengaruh karakter agroekologi terhadap produktivitas karet, dilakukan analisis regresi di mana faktor-faktor tanah sebagai karakter agroekologi lahan sebagai peubah bebas dan hasil karet sebagai peubah tidak bebas. Data hasil karet yang digunakan dalam analisis adalah hasil karet per ha pada lokasi yang diamati karakter lahannya, sementara karakter lahan yang digunakan adalah data hasil analisis tanah pada titik-titik pengamatan. Data hubungan antara karakter tanah dan hasil karet lokasi kajian disajikan pada Tabel 5 .

Tabel 5. Hasil karet dan kesuburan kimia tanah perkebunan karet di Lampung.

\begin{tabular}{|c|c|c|c|c|c|c|c|}
\hline Kabupaten/Lokasi & Hasil (ton ha ${ }^{-1}$ ) & $\mathrm{pH}$ & $\mathrm{N}(\%)$ & $\begin{array}{l}\text { P HCl } 25 \% \\
\left({\left.\mathrm{mg} 100 \mathrm{~g}^{-1}\right)}\right.\end{array}$ & $\begin{array}{l}\mathrm{K} \mathrm{HCl} 25 \% \\
\left(\mathrm{mg} 100 \mathrm{~g}^{-1}\right)\end{array}$ & $\begin{array}{c}\text { C-organik } \\
(\%)\end{array}$ & $\begin{array}{c}\mathrm{Al}_{\mathrm{dd}} \\
\left(\mathrm{cmol} \mathrm{kg}^{-1}\right) \\
\end{array}$ \\
\hline Tulang Bawang & 1.60 & 4.29 & 0.17 & 15.72 & 59.47 & 3.16 & 1.65 \\
\hline Tulang Bawang & 2.70 & 4.53 & 0.22 & 16.14 & 45.91 & 2.98 & 1.70 \\
\hline Tulang Bawang & 1.10 & 4.50 & 0.17 & 17.34 & 45.41 & 2.49 & 1.45 \\
\hline Tulang Bawang & 2.70 & 4.74 & 0.24 & 18.38 & 42.34 & 2.47 & 1.15 \\
\hline Tulang Bawang & 1.90 & 4.49 & 0.19 & 16.25 & 45.76 & 2.38 & 1.00 \\
\hline Tulang Bawang & 1.00 & 4.34 & 0.15 & 15.16 & 49.43 & 2.16 & 1.50 \\
\hline Tulang Bawang & 2.10 & 4.63 & 0.24 & 14.26 & 49.69 & 2.08 & 1.25 \\
\hline Tulang Bawang & 1.80 & 4.49 & 0.21 & 15.35 & 44.20 & 2.04 & 1.30 \\
\hline Tulang Bawang & 1.30 & 4.36 & 0.17 & 18.42 & 46.68 & 2.03 & 2.15 \\
\hline Tulang Bawang & 2.10 & 4.74 & 0.20 & 16.45 & 41.35 & 2.01 & 1.75 \\
\hline Lampung Tengah & 2.00 & 4.43 & 0.23 & 40.16 & 15.37 & 2.15 & 2.25 \\
\hline Lampung Tengah & 2.00 & 4.49 & 0.19 & 32.85 & 17.33 & 2.04 & 2.20 \\
\hline Lampung Tengah & 2.50 & 4.27 & 0.19 & 15.98 & 8.21 & 1.87 & 1.50 \\
\hline Lampung Tengah & 2.50 & 4.45 & 0.20 & 20.19 & 10.35 & 2.07 & 1.15 \\
\hline Lampung Tengah & 2.50 & 4.28 & 0.22 & 13.87 & 18.94 & 2.05 & 1.15 \\
\hline Lampung Tengah & 2.50 & 3.88 & 0.19 & 11.98 & 14.36 & 1.97 & 1.10 \\
\hline Lampung Tengah & 2.50 & 4.37 & 0.20 & 19.79 & 15.19 & 1.96 & 1.05 \\
\hline Lampung Tengah & 2.50 & 4.28 & 0.19 & 20.17 & 14.87 & 1.88 & 1.05 \\
\hline Lampung Tengah & 3.00 & 4.57 & 0.20 & 25.96 & 13.71 & 2.10 & 1.00 \\
\hline Lampung Tengah & 3.00 & 4.54 & 0.19 & 29.41 & 13.99 & 1.77 & 0.95 \\
\hline Way Kanan & 1.20 & 4.44 & 0.21 & 20.37 & 60.88 & 2.36 & 2.95 \\
\hline Way Kanan & 1.50 & 4.50 & 0.24 & 19.45 & 53.28 & 3.85 & 2.05 \\
\hline Way Kanan & 1.68 & 4.47 & 0.36 & 41.73 & 55.99 & 2.39 & 1.50 \\
\hline Way Kanan & 1.80 & 4.48 & 0.21 & 20.15 & 42.46 & 2.79 & 1.50 \\
\hline Way Kanan & 1.92 & 5.27 & 0.30 & 20.69 & 65.43 & 3.59 & 1.45 \\
\hline Way Kanan & 1.92 & 4.77 & 0.23 & 18.82 & 49.51 & 2.66 & 1.45 \\
\hline Way Kanan & 2.04 & 4.43 & 0.20 & 17.66 & 51.47 & 2.69 & 1.20 \\
\hline Way Kanan & 2.10 & 4.44 & 0.24 & 18.97 & 41.18 & 3.25 & 1.10 \\
\hline Way Kanan & 2.10 & 4.63 & 0.22 & 19.21 & 51.76 & 2.75 & 0.85 \\
\hline Way Kanan & 2.40 & 4.45 & 0.21 & 24.93 & 49.09 & 2.89 & 0.35 \\
\hline
\end{tabular}

Hasil analisis regresi hubungan faktor tanah dan hasil karet di Tulang Bawang menunjukkan bahwa ada hubungan yang erat antara faktor tanah dan hasil karet di Tulang Bawang seperti ditunjukkan pada persamaan regresi berikut:

$\mathrm{Y}^{\prime}=-2.53+0.03 \mathrm{X} 1+14.76 \mathrm{X} 2-0.03 \mathrm{X} 3-0.03 \mathrm{X} 4+$ $0.66 \times 5+0.23 \times 6$;

$\mathrm{R}=0.95 ; \mathrm{R}^{2}=0.91$ dan $\mathrm{R}^{2}$ disesuaikan $=0.72 ;$ di mana:

$\mathrm{X} 1=\mathrm{pH} ; \mathrm{X} 2=\mathrm{N} ; \mathrm{X} 3=\mathrm{P} ; \mathrm{X} 4=\mathrm{K} ; \mathrm{X} 5=$ C-organik dan $\mathrm{X} 6=\mathrm{Al}$.

Berdasarkan hasil analisis tersebut, besarnya sumbangan pengaruh faktor tanah terhadap hasil karet adalah $72 \%$ seperti yang ditunjukkan $\mathrm{R}^{2}$. Persamaan regresi menunjukkan bahwa bila variabel faktor tanah 0 , maka hasil karet -2.53 ton $\mathrm{ha}^{-1}$. Unsur hara $\mathrm{P}$ dan $\mathrm{K}$ berkorelasi negatif terhadap hasil karet, namun pengaruhnya sangat kecil.

Hasil analisis regresi hubungan faktor tanah dengan hasil karet di Lampung Tengah menunjukkan bahwa terdapat hubungan yang erat antara faktor tanah dan hasil karet, namun sumbangan pengaruhnya terhadap hasil karet kecil. Hasil analisis regresi hubungan tersebut ditunjukkan pada persamaan regresi berikut:

$$
\begin{aligned}
\mathrm{Y}^{\prime}= & 2.656+0.251 \mathrm{X} 1-0.573 \mathrm{X} 2+0.011 \mathrm{X} 3-0.014 \mathrm{X} 4 \\
& -0.128 \mathrm{X} 5-0.693 \mathrm{X} 6 ; \\
& \mathrm{R}=0.927 ; \mathrm{R}^{2}=0.859 ; \mathrm{R}^{2} \text { disesuaikan = } 0.576 ;
\end{aligned}
$$


di mana :

$\mathrm{X} 1=\mathrm{pH} ; \mathrm{X} 2=\mathrm{N} ; \mathrm{X} 3=\mathrm{P} ; \mathrm{X} 4=\mathrm{K} ; \mathrm{X} 5=\mathrm{C}$-organik dan $\mathrm{X} 6=\mathrm{Al}$.

Sumbangan pengaruh faktor tanah terhadap hasil karet di Lampung Tengah hanya sebesar 57.6 \%, sisanya dipengaruhi faktor lain yang tidak dimasukkan kedalam analisis.

Persamaan regresi tersebut menunjukkan bahwa bila semua variabel tanah bernilai 0 , maka hasil karet bisa mencapai 2,656 ton $\mathrm{ha}^{-1}$. $\mathrm{pH}$ tanah dan $\mathrm{P}$ berpengaruh positif terhadap hasil karet di Lampung Tengah, namun kadar Al berpengaruh negatif. Hal ini disebabkan karena peningkatan kadar Al dalam tanah menfiksasi (mengikat) unsur hara $\mathrm{P}$ dalam tanah sehingga tidak tersedia bagi tanaman. Oleh karena itu walaupun kadar P tinggi dalam tanah, namun karena terfiksasi oleh $\mathrm{Al}$, maka tidak dapat diserap oleh tanaman.

Hasil analisis regresi hubungan faktor tanah dan hasil karet di Way Kanan menunjukkan, bahwa terdapat hubungan yang kuat antara faktor tanah dengan hasil karet seperti terlihat pada persamaan regresi berikut:

$\mathrm{Y}^{\prime}=2.799+0.005 \mathrm{X} 1+0.569 \mathrm{X} 2-0.013 \mathrm{X} 3+0.002 \mathrm{X} 4-$ $0.061 \times 5-0.497 \mathrm{X} 6$;

$\mathrm{R}=0.99 ; \mathrm{R}^{2}=0.98$ dan $\mathrm{R}^{2}$ disesuaikan $=0.94 ;$ di mana :

$\mathrm{X} 1=\mathrm{pH} ; \mathrm{X} 2=\mathrm{N} ; \mathrm{X} 3=\mathrm{P} ; \mathrm{X} 4=\mathrm{K} ; \mathrm{X} 5=\mathrm{C}$-organik dan $\mathrm{X} 6=\mathrm{Al}$.

Berdasarkan hasil analisis regresi di atas, besarnya sumbangan pengaruh faktor tanah terhadap hasil karet adalah $94 \%$, bila variabel tanah bernilai 0, hasil karet 2,799 ton $\mathrm{ha}^{-1}$, namun kadar $\mathrm{Al}$ berpengaruh nyata terhadap penurunan hasil karet.

Analisis varians (Tabel 6) menunjukkan adanya pengaruh nyata faktor tanah terhadap hasil karet di Way Kanan. Secara parsial faktor tanah yang berpengaruh nyata terhadap hasil karet tersebut adalah kandungan Al dalam tanah.

Berdasarkan data pada Tabel 3, lahan perkebunan karet di tiga lokasi tersebut tergolong ke dalam kelas S2 yang ditunjukkan oleh $\mathrm{pH}$ tanah kurang dari 5 sebagai salah satu faktor pembatas produksi. Faktor $\mathrm{pH}$ berkaitan dengan kadar $\mathrm{Al}_{\mathrm{dd}}$ berada pada status sedang sampai tinggi (Tabel 4) dan hasil analisis varians (Tabel 6) yang menunjukkan bahwa $\mathrm{pH}$ berpengaruh nyata terhadap hasil karet.

Tabel 6. Analisis varians hubungan antara faktor tanah dan hasil karet di Way Kanan.

\begin{tabular}{lccccc}
\hline \multicolumn{1}{c}{ Model } & $\begin{array}{c}\text { Jumlah } \\
\text { Kuadrat }\end{array}$ & Df & $\begin{array}{c}\text { Kuadrat } \\
\text { Tengah }\end{array}$ & F & $\begin{array}{c}\text { Beda Nyata } \\
(5 \%)\end{array}$ \\
\hline Regresi & 1.027 & 6 & 0.171 & 25.306 & $0.012^{*}$ \\
Residual & 0.020 & 3 & 0.007 & & \\
Toal & 1.047 & 9 & & & \\
\hline Keterangan ** &
\end{tabular}

Keterangan : $*$ nyata pada taraf $5 \%$

\section{SIMPULAN}

1. Karakteristik agroekologi perkebunan karet di Lampung termasuk ke dalam kelas sesuai (S2), dengan faktor pembatas untuk Lampung Tengah dan Tulang Bawang adalah bulan kering lebih dari 3 bulan dan $\mathrm{pH}$ tanah yang rendah $(<5)$ dapat menghambat produksi karet, sedangkan di Way Kanan, faktor pembatasnya adalah kadar $\mathrm{Al}_{\mathrm{dd}}$ dalam tanah tinggi.
2. Tingkat kesuburan tanah perkebunan karet di semua lokasi rata-rata pada taraf rendah sampai sedang, kecuali kadar K potensial di Tulang Bawang dan Way Kanan tinggi dan $\mathrm{P}$ tersedia di semua lokasi tinggi. $\mathrm{pH}$ tanah yang rendah dan kadar $\mathrm{Al}_{\mathrm{dd}}$ pada taraf sedang sampai tinggi pada lapisan 20-40 $\mathrm{cm}$ di bawah permukaan tanah berpotensi untuk memfiksasi hara $\mathrm{P}$ sehingga tidak tersedia bagi tanaman.

3. Terdapat hubungan yang sangat kuat antara faktor tanah dan hasil karet di Tulang Bawang dan Way Kanan yang ditunjukkan oleh $\mathrm{R}^{2}$ disesuaikan masingmasing 0.72 dan 0.94, sedangkan di Lampung Tengah hubungannya lemah dengan nilai $\mathrm{R}^{2}$ disesuaikan 0.576 .

\section{UCAPAN TERIMA KASIH}

kepada:

Penulis menyampaikan ucapan terima kasih

1. Kemenertian Riset dan Teknologi sebagai penyandang dana dalam pelaksanaan kajian ini melalui program "Insentif Peningkatan Kemampuan Peneliti dan Perekayasa Kementerian Riset dan Teknologi".

2. Soraya, SP; Bambang Wijayanto dan Dani Purwadi yang telah membantu dalam pelaksanaan kajian ini hingga selesai.

\section{DAFTAR PUSTAKA}

Anwar, C. 2006. Manajemen dan teknologi budidaya karet. Makalah disampaikan pada pelatihan "Tekno Ekonomi Agribisnis Karet" PT. FABA Indonesia Konsultan, Jakarta. 24 halaman.

Balai Penelitian Tanah. 2003. Petunjuk Teknis Penyusunana Peta Satuan Evaluasi Lahan Untuk Pewilayahan Komoditas Pertanian Skala 1:50,000 Melalui Analisis Terrain. Pusat Penelitian dan Pengembangan Tanah dan Agroklimat. 22 halaman.

BPS Lampung. 2013. Luas areal dan produksi tanaman perkebunan rakyat, perkebunan besar Negara, perkebunan besar suasta di Provinsi Lampung. halaman 337-347.

Dinas Perkebunan Provinsi Lampung. 2012. Komoditas Perkebunan Unggulan (Komoditi Karet). 22 halaman.

Djaenudin, D., M. Marwan, H. Subagyo, Anny Mulyani dan N. Suharta. 2000. Kriteria Kesesuaian Lahan untuk Komoditas Pertanian. Pusat Penelitian Tanah dan Agroklimat, Bogor.

FAO, 1983. Land Suitability Classification For Rain-Fed Agriculture.

http://binaukm.com. 2010. Persyaratan tumbuh tanaman karet dalam budidaya tanaman karet.

http://gtuneland.wordpress.com. 2011. Pengaruh unsurunsur iklim dan faktor pembatas utama pada tanaman karet. Interaksi kinerja klon karet dengan unsur - unsur iklim. 
Ritiung, S., Wahyunto, F. Agus, dan H. Hidayat. 2007. Panduan evaluasi kesesuaian lahan dengan contoh peta arahan penggunaan lahan Kabupaten Aceh Besar. Balai Penelitian Tanah dan World Agroforestry Centre. 48 halaman.

Sasongko, P.E. 2010. Studi kesesuaian lahan potensial untuk tanaman kelapa sawit di Kabupaten blitar. Jurnal Pertanian MAPETA, 12: 72 - 134.
Schmidt, F.A. and J.H.A. Ferguson. 1951. Rainfall Types Based on Wet and Dry Period Ratios for Indonesia with Western New Guinea. Verh. No. 42, Djawatan Meteorologi dan Geofisika, Kementrian Perhubungan, Jakarta. 